Nippon Suisan Gakkaishi $\quad$ 71(5), 736-745 (2005)

\title{
標識放流試験から見たトラフグ親魚の 伊勢湾口部産卵場への回帰
}

\author{
中島博司, $1 *$ 新田 朗 2 \\ （2004 年 6 月 11 日受付, 2005 年 2 月 10 日受理） \\ 1三重県科学技術振興センター水産研究部, ${ }^{2}$ 日本エヌ・ユー・エス株式会社
}

Homing behavior of adult ocellate puffer Takifugu rubripes to the natal spawning ground at the mouth of Ise Bay based on tagging experiments

HIROSHI NAKAJIMA ${ }^{*}$ AND AKIRA NITTA ${ }^{2}$

${ }^{1}$ Mie Prefectural Science and Technology Promotion Center, Fisheries Research Division, Shima, Mie 517-0404, 2Japan NUS Co., Ltd., Minato, Tokyo 108-0022, Japan

In order to clarify the homing behavior of ocellate puffer Takifugu rubripes to the natal spawning ground, adult ocellate puffers of total length $37-60 \mathrm{~cm}$ caught by purse seine net at the spawning ground off Anori, Mie Prefecture, were released at a location 3 miles south of the spawning ground with disk tags attached in 1996, 1997 and archival tags attached in 1998. The numbers of individuals released in 1996, 1997 and 1998 were 217, 69 and 5, and respectively 58, 14 and 3 fish were recaptured within the area of Ise Bay, Kumano Nada and Enshu Nada. Four individuals released in 1996 and one in 1998 apparently returned to the same spawning ground in the next spawning season after being released. One individual released in 1997 was recaptured very close to the spawning ground off Anori in April 1998. These results imply that adult ocellate puffer return to the same spawning ground and strongly support that this species shows homing behavior to the natal spawning ground. The fish with archival tags implanted were distributed almost within a $\pm 2^{\circ}$ longitudinal area around the release and recapture location. It is concluded that adult ocellate puffer seldom migrate in and out between the Kumano and Enshu Nada area and other areas.

キーワード : アーカイバルタグ, 産卵回帰, 産卵場, トラフグ, 標識放流

熊野灘・遠州灘に生息するトラフグ Takifugu rubripes は, 一部の地区でタイ延縄漁業の副産物として漁閑 期に漁獲される程度であったが, 1975 年頃から漁業資 源としての価值が高まった。その後, 三重県安乗, 愛知 県日間賀, 静岡県浜名地区の延縄漁業者によって, 1978 年には漁期 (10月から 2 月), 漁法（底延縄に限 る）の制限，1989 年には体重 $600 \mathrm{~g}$ 以下は再放流とす る漁獲サイズの制限等の自主的な資源管理が設けられて きた。ところが, 1989 年漁期には三重, 愛知, 静岡三 県の漁獲量は約 400 トンと史上かってない大豊漁とな り，これを契機に三県の新規延縄漁業者数は数倍に激増 し, 漁獲圧も一気に高まった。一方で, 本種の当海域に おける生態が全く把握されていない中でこの豊漁現象の 解明が始まり, 船越 ${ }^{1}{ }^{1}$ は紀伊半島沿岸から志摩半島沿岸
を産卵場とするローカル資源の存在の可能性を示唆し た。中島 ${ }^{2}$ も, 伊勢湾で混獲される当歳魚の漁獲量と翌 年に熊野灘・遠州灘に打いて延縄で漁獲される 1 才魚 の漁獲量に正の相関が見られることから, 豊漁は他海域 に生息するトラフグの回遊によるものではなく伊勢湾に 由来する資源によるものと推察した。トラフグ資源への 関心が高まる中で, 熊野灘・遠州灘海域に生息する本種 の資源生態調查研究が本格的に着手され, 未成魚, 成魚 等の分布移動, ${ }^{2-4)}$ 伊勢湾口部安乗沖産卵場の存在 ${ }^{5}$ が次 々に明らかにされた。これらの知見から, 熊野灘・遠州 灘海域に生息するトラフグは, 伊勢湾口部に産卵場を有 し, 他海域とは独立した系群であると推定されるように なった。6) 熊野灘・遠州灘海域のトラフグ漁獲量は 1989 年以降大きな年変動を繰り返しており, 漁獲量の安定化

* Tel : 81-599-53-0130. Fax : 81-599-53-2225. Email : nakajh01@pref.mie.jp 
や資源の維持増大を図るためには適正な資源管理や栽培 漁業の推進が求められている。そして, トラフグの資源 管理や栽培漁業を推進するためには, 熊野灘・遠州灘海 域のトラフグが 1 つの独立した個体群であることを明 確にしておく必要がある。

佐藤ら ${ }^{7)}$ は, トラフグは「生まれ故郷の産卵場へ回帰 して産卵する」と言う仮説を立て, 瀬戸内海の産卵場に おいてトラフグ親魚を用いた標識放流試験を行い，標識 魚が翌年同じ産卵場に回帰することを証明した。本研究 では, 熊野灘・遠州灘海域の中央部に位置する伊勢湾口 部安乗沖産卵場において初めてディスクタグを用いた産 卵親魚の標識放流試験を 1996 年, 1997 年の 2 力年間 行うとともに, 1998 年には位置推定が可能なアーカイ バルタグを併用して, 従来の標識手法では把握できない 連続的な移動回遊を追跡することにより, 熊野灘・遠州 漢海域に生息するトラフグ親魚の産卵場への回帰性を検 討した。

\section{材料および方法}

標識放流の方法 本研究では, 伊勢湾湾口に位置する 鳥羽市離島から大王町波切に至る三重県沖合海域を伊勢 湾口部と呼ぶ（Fig. 1)。供試魚は伊勢湾口部安乗沖の 産卵場で操業するまき網で漁獲されたトラフグ親魚であ る。漁獲されたトラフグは, 啮反合いを防止するため直 ちに歯切りされることから, 筆者は船上で噛み合い傷が 少なく活力の良好な個体を選別し，それらを仕切り板の ついた塩ビ製の活魚輸送用籠に収容した。その後, さら にこれらのトラフグを運搬船で船上輸送し, 安乗魚市場 の活魚水槽に収容した。標識放流試験の概要は次のとお りである。1996 年 4 月 22 日から 5 月 7 日にかけては

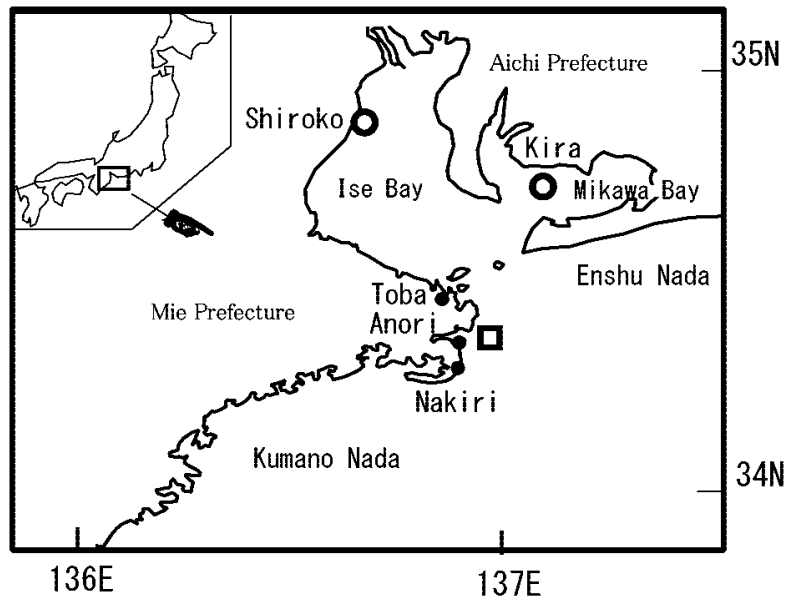

Fig. 1 Locations where tagged adult ocellate puffer were released $(\square)$, and daily water temperature was monitored $(O)$. The mouth of Ise Bay is the open ocean from Toba to Nakiri off Mie Prefecture.
全長 $37 \sim 60 \mathrm{~cm}$ （平均全長 $42.7 \mathrm{~cm}$ ） のトラフグ 217 個 体に，1997 年 4 月 29 日には全長 $37 \sim 44.1 \mathrm{~cm}$ (平均全 長 $40.3 \mathrm{~cm}$ ）のトラフグ 69 個体の背䰹基部にディスク タグを装着し, 放流直後の再捕をさけるため, 産卵場よ り約 3 マイル南の地点に放流した（Fig. 1, Table 1)。 さらに, 1998 年 4 月 11 日には, 全長 $41 \sim 53 \mathrm{~cm}$, 体重 1,145 3,580 g の 5 個体にアーカイバルタグ（NMT 社 製) $)^{8)}$ を腹腔内に挿入するとともにディスクタグとの二 重標識を行い，ディスクタグ装着魚と同様に産卵場より 約 3 マイル南の地点（北緯 34 度 20 分，東経 136 度 59 分）に放流した。放流魚は全長組成（Fig. 2) および年 齢に関する過去の知見9,10) から, 満 2 才魚主体に 3 歳以 上魚が混じる年齢構成であったことが推察される。

アーカイバルタグの設定および取得データの解析方法 アーカイバルタグは, 外部水温, 腹腔内温度, 水圧, 照 度の 4 項目を計測し, 計測時刻とともにタイムシリー ズログファイルとしてタグ内部に記録, 保存する。これ ら 4 項目のデータは, 128 秒の整数倍の間隔で記録する ように設定できる。このファイルはデータ取得開始後と 取得終了前の 2 領域に分割されて抢り, メモリ一容量 に制限があるために，放流から回収までの期間が長い場

Table 1 The outline of tagging experiments using adult ocellate puffer caught at the spawning ground

\begin{tabular}{ccccc}
\hline Date of release & $\begin{array}{c}\text { Number } \\
\text { of fish }\end{array}$ & $\begin{array}{c}\text { Average total } \\
\text { length (range) }\end{array}$ & $\begin{array}{c}\text { Tagging } \\
\text { method }\end{array}$ \\
\hline 1996 & $\begin{array}{c}\text { 22 April- } \\
7 \text { May }\end{array}$ & 217 & $\begin{array}{c}42.7 \mathrm{~cm} \\
(37-60 \mathrm{~cm})\end{array}$ & Disk tag \\
1997 & 29 April & 69 & $\begin{array}{c}40.3 \mathrm{~cm} \\
(37-44 \mathrm{~cm})\end{array}$ & Disk tag \\
1998 & 11 April & 5 & $\begin{array}{c}46.0 \mathrm{~cm} \\
(41-53 \mathrm{~cm})\end{array}$ & $\begin{array}{c}\text { Archival tag } \\
\text { and disk tag }\end{array}$ \\
\hline
\end{tabular}

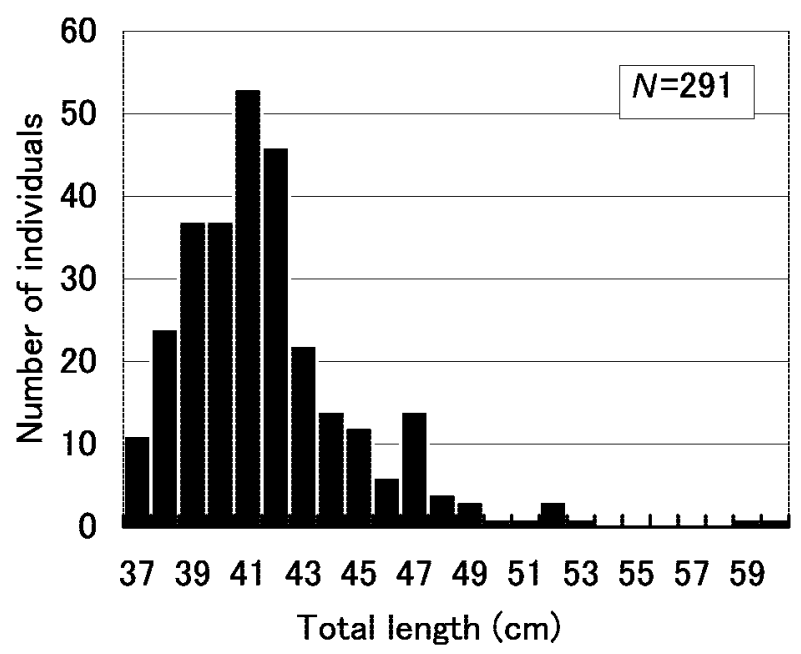

Fig. 2 Frequency distribution in total length of adult ocellate puffer released during 1996-1998. 
合には途中のデータが上書き保存によって消去されてい く。本研究では, データの記録は 256 秒間隔とし, 2 つ の領域に放流後 80 日間と再捕（タグ回収）前 80 日間 の合計 160 日間のデータが保存されるように設定し た。また, タイムシリーズログファイルとは別に, 照度 の計測值から推定した毎日の日出, 日没の時刻, 日出, 日没の時刻から計算される緯度経度, 並びに設定した 3 層（本研究では $0 \mathrm{~m}, 30 \mathrm{~m}, 60 \mathrm{~m}$ に設定した）の遊泳時 の外部水温がデイログファイルとして記録, 保存され た。

このアーカイバルタグを用いた位置推定には, 前述し たとおり日出時刻と日没時刻が使われる。したがって, 推定精度は標識魚が遊泳する場所における日出および日 没時刻が正確に計測できたかどうかに左右される。トラ フグの場合, 養殖魚が養殖場の泥などに体を埋める埋没 行動を行うことが良く知られている。11) アーカイバルタ グを装着した標識魚の遊泳行動からも埋没と推測される 行動が頻繁に出現し, ${ }^{8)}$ 本来記録されるべき日出および 日没時刻が正確に計測されないことがあると考えられ た。12）そこで，位置推定値から埋没行動によると考えら れる異常な推定值を取り除いた。

位置推定は水温情報を用いることにより補正が可能と 考えられている。13) 今回再捕されたアーカイバルタグ標 識魚は後述するように水深 $10 \mathrm{~m}$ 以浅の表層を遊泳して いることが多かったので, タグに記録された水温と推定 された位置付近における表面水温の観測値が明らかに異 なる場合も異常な位置推定値として処理した。水温情報 は, 三重県科学技術振興センター水産研究部が発行して いる人工衛星海況速報, 東京都, 千葉県, 神奈川県, 静 岡県の各水産試験場が発行している一都三県漁海況速報
および和歌山県, 高知県の海況観測結果（漁況海況予報 事業結果報告書）を用いた。さらに，タイムシリーズロ グファイルに記録された任意の時刻の水温データと人工 衛星海況速報（水産研究部発行）打よびFig. 1 に示し た伊勢湾湾奥部に位置する鈴鹿市白子地先表面水温（水 産研究部鈴鹿水産研究室観測, 午前 9 時頃観測), 伊勢 湾湾口部に近い三河湾吉良の水深 $3.5 \mathrm{~m}$ に打淀地水 温（愛知県水産試験場発行三河湾海況観測旬報, 日平均 值）を用いて，推定位置の精度を検証した。なお，ここ では三河湾吉良の定地水温の日平均值は概数午前 10 時 の観測值で代表されるとした。14)一方, タイムシリーズ ログファイルの外部水温は, トラフグが必ずしも午前 9 時から 10 時頃に抢いて水深 $10 \mathrm{~m}$ 以浅の表層を遊泳し ていない場合があったため, 午前 8 時から 11 時の時間 帯を適用した。また，外部水温の鉛直变化で水深 $0 \mathrm{~m}$ から $5 \mathrm{~m}$ までの水温はほぼ等しいと考えられたことか ら, タイムシリーズログファイルの外部水温として, こ の時間帯に打ける水深 $5 \mathrm{~m}$ 以浅の水温データの平均値 を用いた。

\section{結果}

ディスクタグ標識の再捕結果 1996 年放流のディス クタグ標識群は 58 個体が再捕され, 再捕率は $26.7 \%$ で あった。放流直後の放流場所周辺での再捕（11 個体） を除き, 季節別に再捕日数, 再捕位置抒よび漁法を Table 2 および Fig. 3 に示した。春季・夏季（5～9 月） は遠州灘抢よび伊勢湾で小型底曳網主体に 18 個体, 熊 野灘, 相模湾でそれぞれ 2 個体, 1 個体が定置網で再捕 された。秋季（10，11月）は遠州灘, 伊勢湾で延縄主 体に 19 個体再捕されたが, 冬季（12〜3 月）の再捕は

Table 2 Detailed records of the recaptured ocellate puffer

\begin{tabular}{|c|c|c|c|c|c|c|}
\hline $\begin{array}{l}\text { Year of } \\
\text { release }\end{array}$ & $\begin{array}{l}\text { Month of } \\
\text { recapture }\end{array}$ & $\begin{array}{l}\text { Number of } \\
\text { fish recaptured }\end{array}$ & $\frac{\mathrm{TL}(\mathrm{cm})^{*}}{(\mathrm{Sex})}$ & $\begin{array}{l}\text { Days at } \\
\text { liberty }\end{array}$ & Location & Fishing method \\
\hline \multirow[t]{6}{*}{1996} & May-September & 18 & $39.3-60.3$ & $9-157$ & Enshu Nada, Ise Bay & Trawl \\
\hline & May-September & 2 & $40.3,44.5$ & $10-25$ & Kumano Nada & Set net \\
\hline & May-September & 1 & 45.6 & 51 & Sagami Bay & Set net \\
\hline & October, November & 19 & $38.1-43.5$ & $156-209$ & Enshu Nada, Ise Bay & Long line, Trawl \\
\hline & April, May & 4 & $38.7-49.9$ & $357-369$ & Mouth of Ise Bay & Purse seine \\
\hline & October-December & 3 & $40.8-45.8$ & $533-581$ & Enshu Nada & Long line \\
\hline \multirow[t]{4}{*}{1997} & May-September & 4 & $36.5-41.8$ & $134-136$ & Enshu Nada, Ise Bay & Boat seine, Trawl \\
\hline & May-September & 1 & 38.9 & 105 & Suruga Bay & Boat seine \\
\hline & October, November & 7 & $39.9-44.2$ & $160-210$ & Enshu Nada, Ise Bay & Long line, Trawl \\
\hline & April, May & 1 & 39.5 & 365 & Mouth of Ise Bay & Trawl \\
\hline \multirow[t]{3}{*}{1998} & June-September & 1 & $40 \quad\left(o^{7}\right)$ & 12 & Enshu Nada & Trawl \\
\hline & October, November & 1 & $51.1($ 우 $)$ & 183 & Kumano Nada & Long line \\
\hline & April, May & 1 & $43 \quad\left(0^{7}\right)$ & 371 & Mouth of Ise Bay & Purse seine \\
\hline
\end{tabular}

\footnotetext{
* Total length (TL) indicates the size at the time of release.
} 

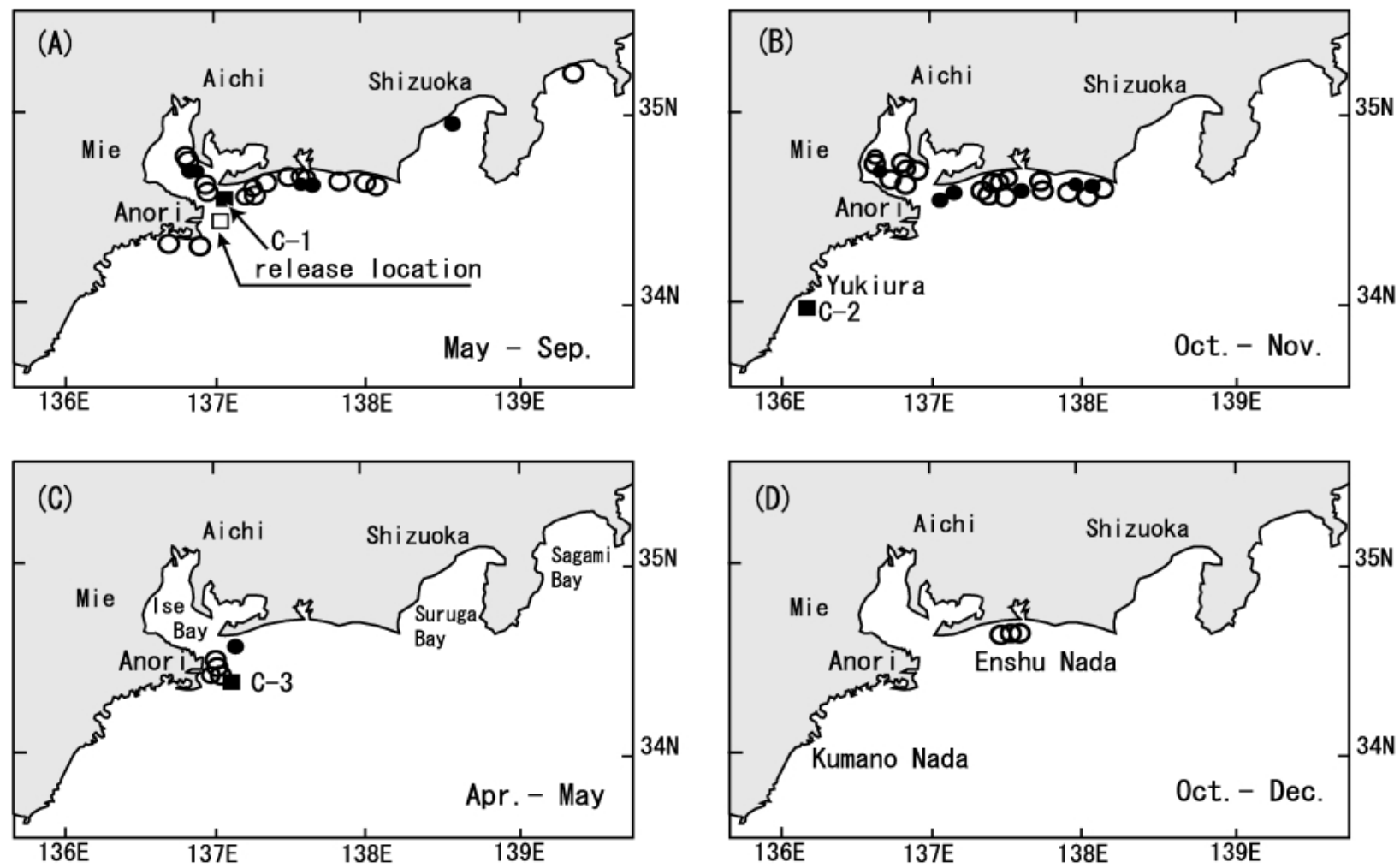

Fig. 3 Recapture points of tagged ocellate puffer. Symbols represent the year that the puffer were released: $0: 1996$; $\bullet: 1997 ; \mathbf{\square}$ : 1998. C-1, C-2 and C-3 show the locations of recaptured fish with the archival tag. (A), (B); recapture in the year of release, (C), (D); recapture in the next year of release.

なかった。しかし，放流後 1 年を経過した翌年の産卵 期には, 同じ伊勢湾口部安乗沖産卵場で 4 月 29 日から 5 月 5 日（357〜369 日目）にかけて再びまき網で 4 個 体が再捕された。さらに，放流後 533 日から 581 日を 経過した秋季（10〜12月）には遠州灘で延縄により 3 個体が再捕された。

1997 年放流のディスクタグ標識群は 14 個体が再捕さ れ，再捕率は $20.3 \%$ であった。放流直後の再捕（1 個 体）を除くと，春季・夏季には遠州灘，伊勢湾，駿河湾 で船曳網, 小型底电網により合計 5 個体, 秋季には主 に遠州灘で延縄主体に 7 個体が再捕されたが，その後 冬季の再捕はなかった（Table 2, Fig. 3)。しかし, 放 流後 1 年を経過した 4 月 29 日（365 日目）に，標識魚 1 個体が伊勢湾口部安乗沖産卵場に近接し, 産卵場から やや北東方向に位置する遠州灘の西部海域で小型底电網 により再捕された。このように, 1996 年と 1997 年の 標識放流試験で再捕された標識魚は, 産卵後主として遠 州灘方面に移動分散するが，産卵期になると再び産卵場 に戻ってくる移動回遊パターンを示し，放流年ごとの差 異は見られなかった。

アーカイバル標識の再捕結果およびタグデータから推 定した推定位置 1998 年放流のアーカイバルタグ標識
群は 3 個体が再捕され，再捕率は $60 \%$ であった。C-1 は 12 日後に伊勢湾口部に近接する遠州灘の西部海域で 小型底曳網により，C-2 は約 6 力月後の 10 月 11 日に 熊野灘遊木浦沖 2 マイルで延縄により, さらにC-3 は 約 1 年後の 1999 年 4 月 16 日に伊勢湾口部の安乗沖産 卵場でまき網により再捕された（Table 2, Fig. 3)。放 流時の大きさおよび再捕後に判別した性別は，それぞれ 全長 $40 \mathrm{~cm}$ の雄, 全長 $51.1 \mathrm{~cm}$ の雌, 全長 $43 \mathrm{~cm}$ の雄 であった。

デイログファイルのデータから推定された 3 個体の 推定位置 (経度) を Fig. 4 に示す。C-1, C-2, C-3 の推 定位置の経度範囲はそれぞれ東経 $136^{\circ} \sim 141^{\circ}$, 東経 $133^{\circ} \sim 139^{\circ}$, 東経 $134^{\circ} \sim 140^{\circ}$ であった。推定範囲は約 $6^{\circ}$ と広く, 日々の推定位置も東西にばらつくことがあっ たが，それらのデータの 85.6〜 90.9\% は東経 $137^{\circ}$ (放 流場所付近）から東西に経度 $2^{\circ}$ の範囲内に分布した。 さらに, C-2 の推定位置は, 放流後から再捕場所に近い 東経 $136^{\circ}$ 付近に多く, 一方, C-3 のそれは, 再捕まで の 1 年間東経 $137^{\circ}$ 付近に多く分布した。

C-3 の放流後から翌年 3 月までの遊泳水深の記録 は, 埋没時を除くと水深 $10 \mathrm{~m}$ 以浅の表層を主体に遊泳 していることを示した（Fig. 5)。特に，4月から6月は 


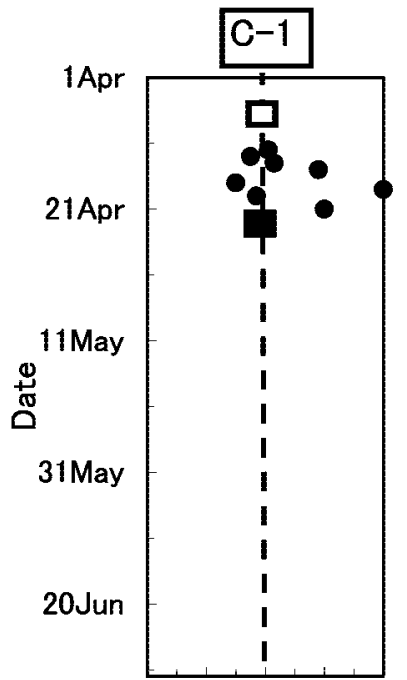

133135137139141

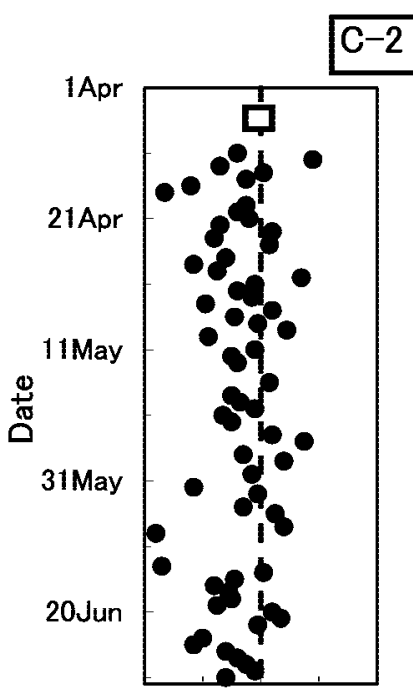

133135137139141

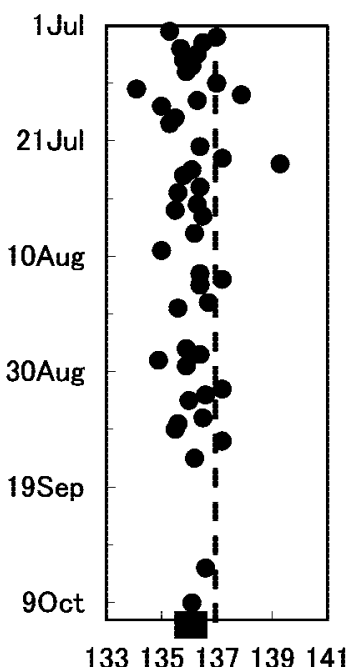

C-3

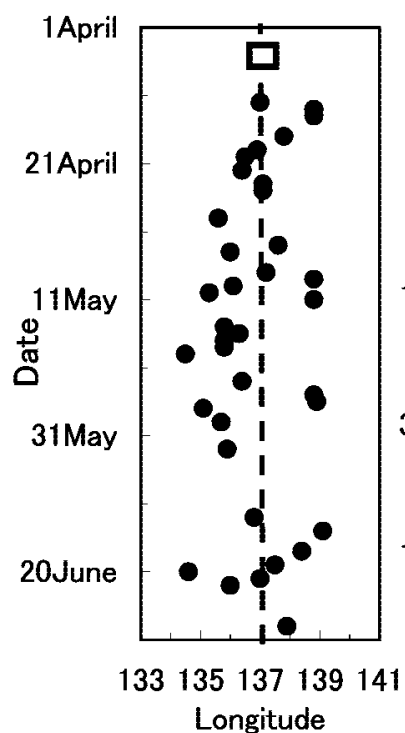

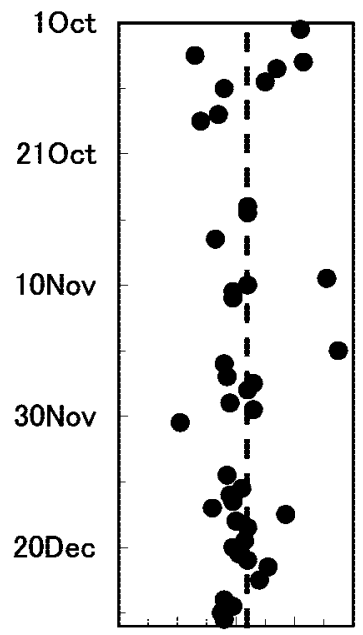

133135137139141 Longitude

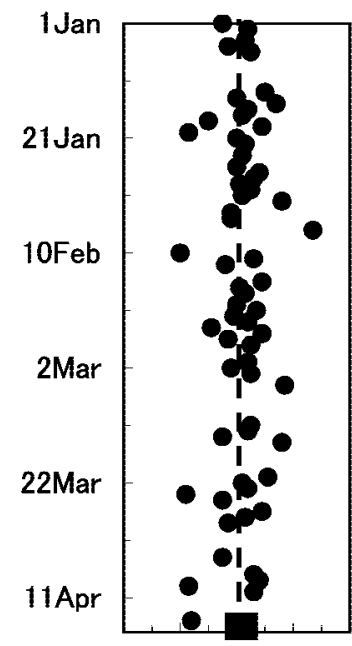

133135137139141 Longitue

Fig. 4 Estimated daily longitudinal positions of C-1, C-2 and C-3 released on April 11, 1998 in the archival tags. The central broken lines in the graphs indicate $137^{\circ} \mathrm{E}$. Open squares and solid squares show the release and recapture positions, respectively.

$5 \mathrm{~m}$ 以浅と浅かった。また，時折 $50 \mathrm{~m}$ から $80 \mathrm{~m}$ 層ま で一気に潜水浮上する鉛直移動を示し，その最大水深は $80 \mathrm{~m}$ （3 月 19 日）であった。しかし，1年後の 4 月に 入って水深 5～ $10 \mathrm{~m}$ 層を小刻みに遊泳するようになり,

4 月 11 日頃からは水深 $10 \mathrm{~m}$ 以深と遊泳層はさらに深 くなる一方, 水深 35〜 $40 \mathrm{~m}$ 層への潜水が顕著になった (Figs. 5, 6)。さらに 4 月 15 日には水深 $33 \mathrm{~m}$ 層を主体 に頻繁に水深 $10 \mathrm{~m}$ 辺りまでの浮上を繰り返す遊泳行動 に大きく変化した後, 翌日の朝 9 時頃にまき網で漁獲 された。

このような $\mathrm{C}-3$ の表層遊泳行動を利用して, タイム シリーズログファイルの得られた期間について, 前述し

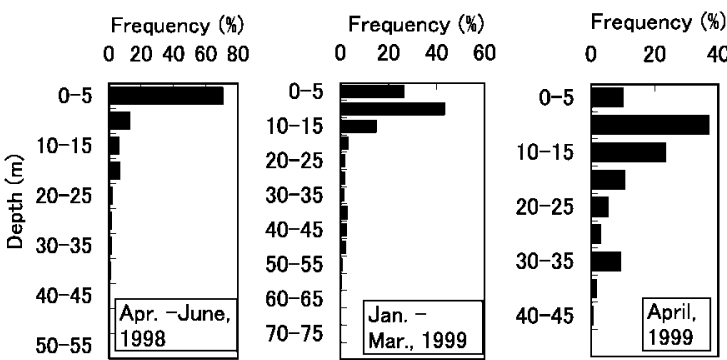

Fig. 5 Frequency distribution of the swimming depth of C-3 during the period from April-June, January-March and April. Vertical axes show the deepest swimming depth. 

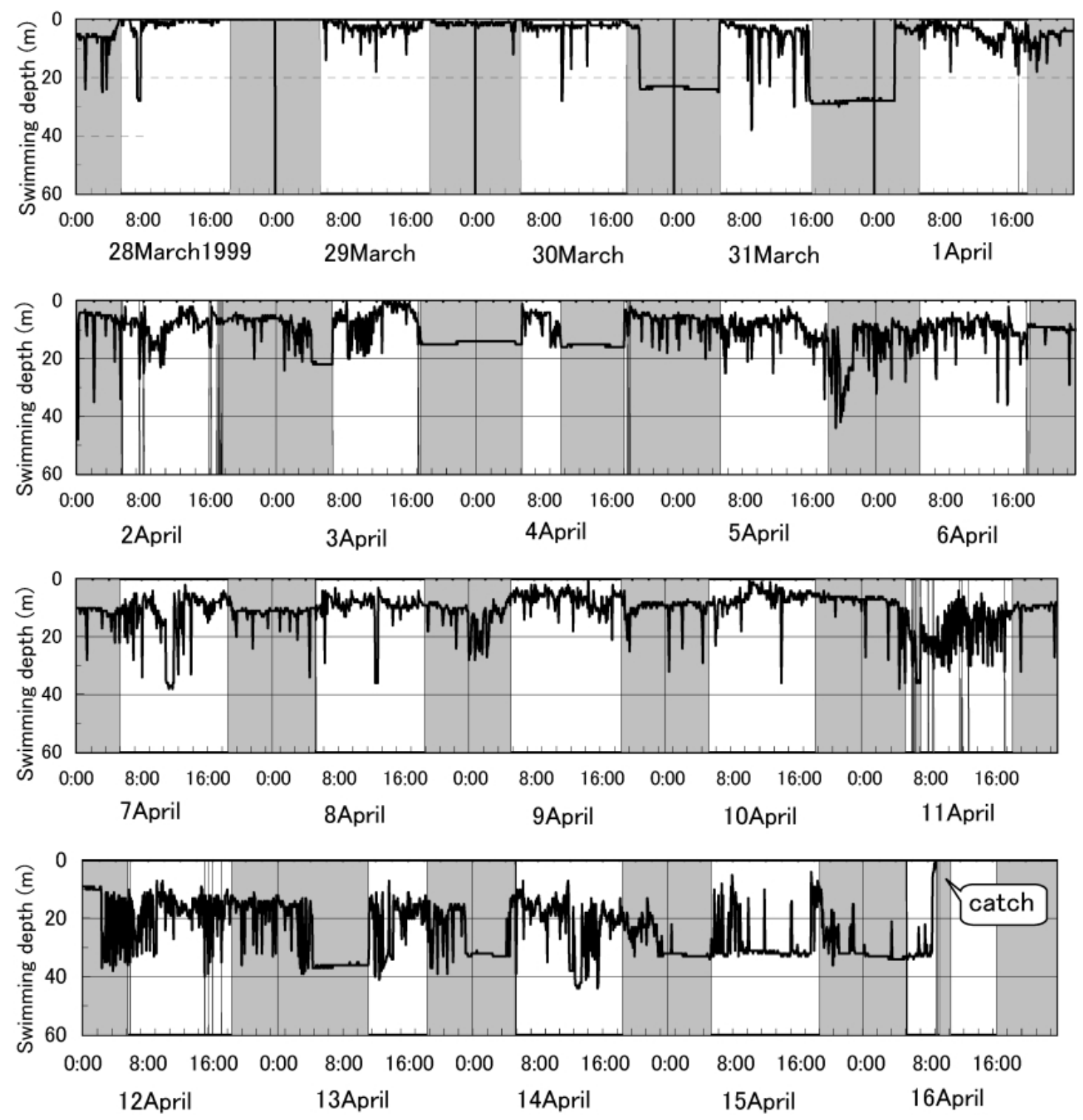

Fig. 6 Vertical swimming depth of C-3 recorded by archival tag from 28 March 1999 to 16 April 1999. The gray shaded zones indicate the time when the tag sensor could not sense light intensity.

た C-3 の推定された位置を定地水温観測結果を用いて 検証した。まず，人工衛星画像が得られた同時刻または その時刻に近い時刻に記録されたタグの外部水温は, 例 えば， 4 月 28 日 6 時 11 分は $18.9^{\circ} \mathrm{C}, 6$ 月 4 日 2 時 23 分は $19.9^{\circ} \mathrm{C}, 5$ 時 56 分は $20.1^{\circ} \mathrm{C}, 6$ 月 29 日 18 時 04 分 は $22.5^{\circ} \mathrm{C}$ であり (Table 3 ), これらの水温を人工衛星 画像の等温線分布に合わせると, 打抢上そ伊勢湾内の水 温分布と一致した (Fig. 7)。そこで, タグが記録した 表層水温と 4 月 26 日から 6 月 30 日末での伊勢湾白子 抢よび三河湾吉良の定地水温を併せて図示すると, タグ の記録した表層の水温変化は比較的吉良の水温変化に良 く一致し, 標識トラフグはこの時期には三河湾周辺海域 （東経 $137^{\circ}$ 付近）に移動分布していることがうかがえた
(Fig. 8)。同様に, 翌年 1 月以降の外部水温について は, 1 月 28 日 15 時 15 分, 29 日 7 時 15 分はそれぞれ $14.7^{\circ} \mathrm{C}, 14.9^{\circ} \mathrm{C}$ を, 2 月 28 日 14 時 30 分, 3 月 1 日 7 時 30 分はそれぞれ $16.6^{\circ} \mathrm{C}, 16.8^{\circ} \mathrm{C}$ を, 3 月 28 日 14 時 15 分, 29 日 7 時 15 分はそれぞれ $15.1^{\circ} \mathrm{C}, 14.7^{\circ} \mathrm{C}$ を記録し た (Table 3$)$ 。この結果から, 標識トラフグは 1 月下旬 から 2 月にかけては伊勢湾口部から遠州灘海域内に, 3 月中旬頃以降は伊勢湾口部抢よびその周辺海域（東経 137 からやや東）に分布したと考えられた（Fig. 9)。 ここで, 人工衛星画像が得られた日のタグの推定経度を Table 3 に併せて示した。なお， 4 月 28 日， 6 月 4 日, 6 月 29 日のデータは得られなかったため, その前後の 日に得られた推定值を見た。この結果, 推定位置は東経 
Table 3 Ambient water temperature and estimated longitude of $\mathrm{C}-3$.

\begin{tabular}{rccc}
\hline Date & Time & $\begin{array}{c}\text { Ambient } \\
\text { temperature } \\
\left({ }^{\circ} \mathrm{C}\right)\end{array}$ & $\begin{array}{c}\text { Estimated } \\
\text { longitude } \\
\left({ }^{\circ} \mathrm{E}\right)\end{array}$ \\
\hline 24 Apr. & - & - & $137.1^{*}$ \\
25 Apr. & - & - & $137.1^{*}$ \\
28 Apr. & $6: 11$ & 18.9 & - \\
29 Apr. & - & - & $135.6^{*}$ \\
2 June & - & - & $135.9^{*}$ \\
4 June & $2: 23,5: 56$ & $19.9,20.1$ & - \\
28 June & - & - & $137.9^{*}$ \\
29 June & $18: 04$ & 22.5 & - \\
1 July & - & - & $136.4^{*}$ \\
\hline 28 Jan. & $15: 15$ & 14.7 & 137.6 \\
29 Jan. & $7: 15$ & 14.9 & 137.1 \\
28 Feb. & $14: 30$ & 16.6 & - \\
1 Mar. & $7: 30$ & 16.8 & 137.4 \\
28 Mar. & $14: 15$ & 15.1 & 137.3 \\
29 Mar. & $7: 15$ & 14.7 & 136.7 \\
\hline
\end{tabular}

Date and time corresponded closely with those of obtained satellite NOAA images

* Estimated longitudes are given for dates around Apr. 28, June 4 and June 29, 1998, because longitude data were not available on these days.

$135.6^{\circ}$ から $137.9^{\circ}$ とやや東西にバラツキがあったが，お 打よそ東経 $137^{\circ}$ 付近を示した。また，翌年 1 月 28 日 29 日, 2 月 28 日 3 月 1 日, 3 月 28 日 29 日の推定位置 は東経 $136.7^{\circ}$ から $137.6^{\circ}$ で，東経 $137^{\circ}$ からやや東を示 した。このように，タグが推定した位置は定地水温を用 いて推定した海域と概ね一致した。

\section{考察}

熊野灘・遠州灘海域におけるトラフグの移動と分布 2 力年間のディスクタグ標識放流試験の結果からトラフ グ親魚の時空間的な移動分布は次のように考えられた。 親魚は産卵後夏季にかけては主に産卵場である伊勢湾口 部から東進して遠州灘に移動する傾向が強く見られた が，一部は伊勢湾内への進入も認められた。この時期に は熊野灘で 2 個体の再捕があり，熊野灘を南下する移 動も認められた。秋季の再捕位置は遠州灘, 伊勢湾であ り，産卵後に分散したトラフグはその後に大きな移動を しないことがうかがえた。1996 年放流のディスクタグ 標識群はさらに約 1.5 年後の秋季にも遠州灘で再捕さ れ，前年と同様に東進して遠州灘に移動した可能性がう かがえた。安井, 濱田 ${ }^{3)}$ が遠州灘打よび駿河湾に抢い て，延縄漁期（10～2月）前から漁期中に実施した標識 放流試験によると，漁期中のトラフグの移動は比較的狭 い範囲に限られていた。伊藤ら4) は，遠州灘に分布する トラフグには，余り大きく移動せず舞阪町沖や御前崎周

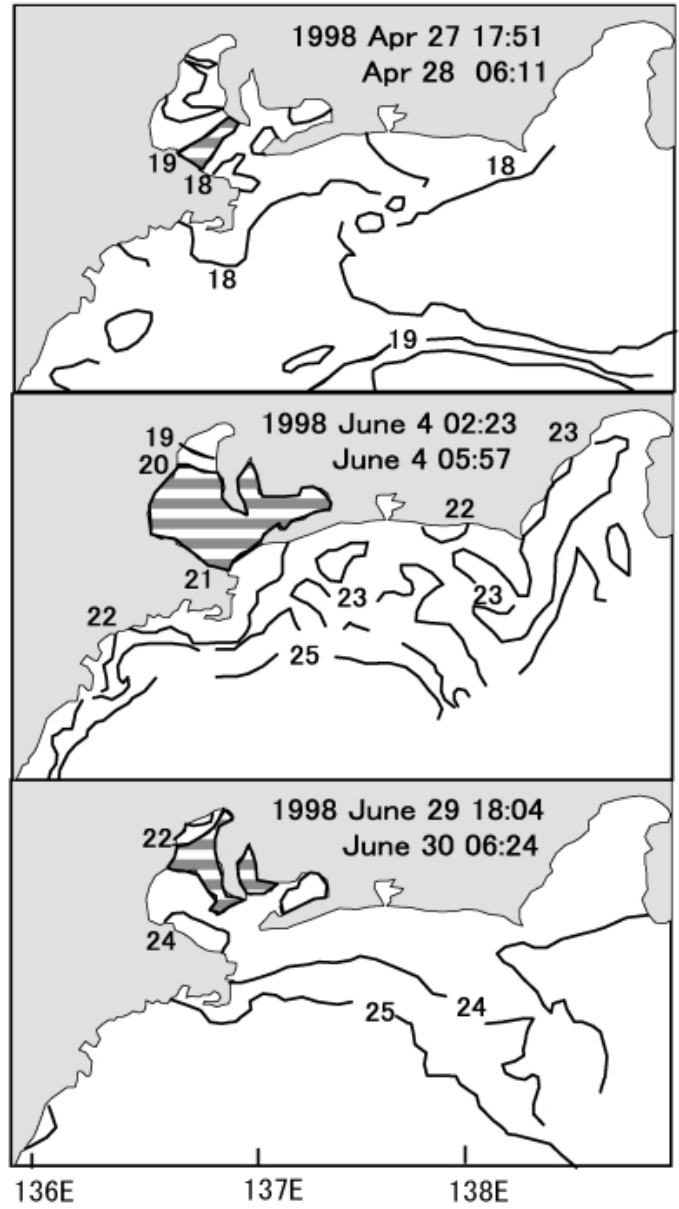

Fig. 7 Sea surface temperature images obtained by the satellite NOAA (April-June). Striped line zones show the estimated distribution areas of $\mathrm{C}-3$.

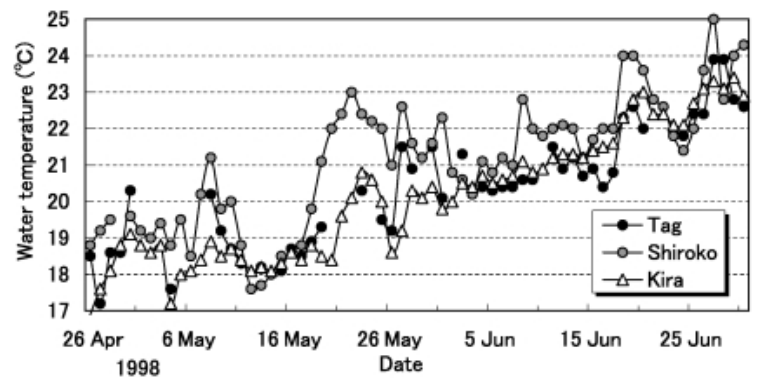

Fig. 8 Relationship between ambient temperature shallower than $5 \mathrm{~m}$ depth recorded by the tag $(\mathrm{C}-3)$ and the daily surface water temperature at Shiroko and Kira stations.

辺で索慨する個体が存在すると考えている。これらのこ とから，トラフグは産卵後遠州灘，熊野灘へ索䬣回遊す ると考えられるとともに，遠州灘海域内では翌年の産卵 期まで大きな移動をすることはないと推察された。

アーカイバルタグ標識魚 C-1 は放流直後に伊勢湾口 


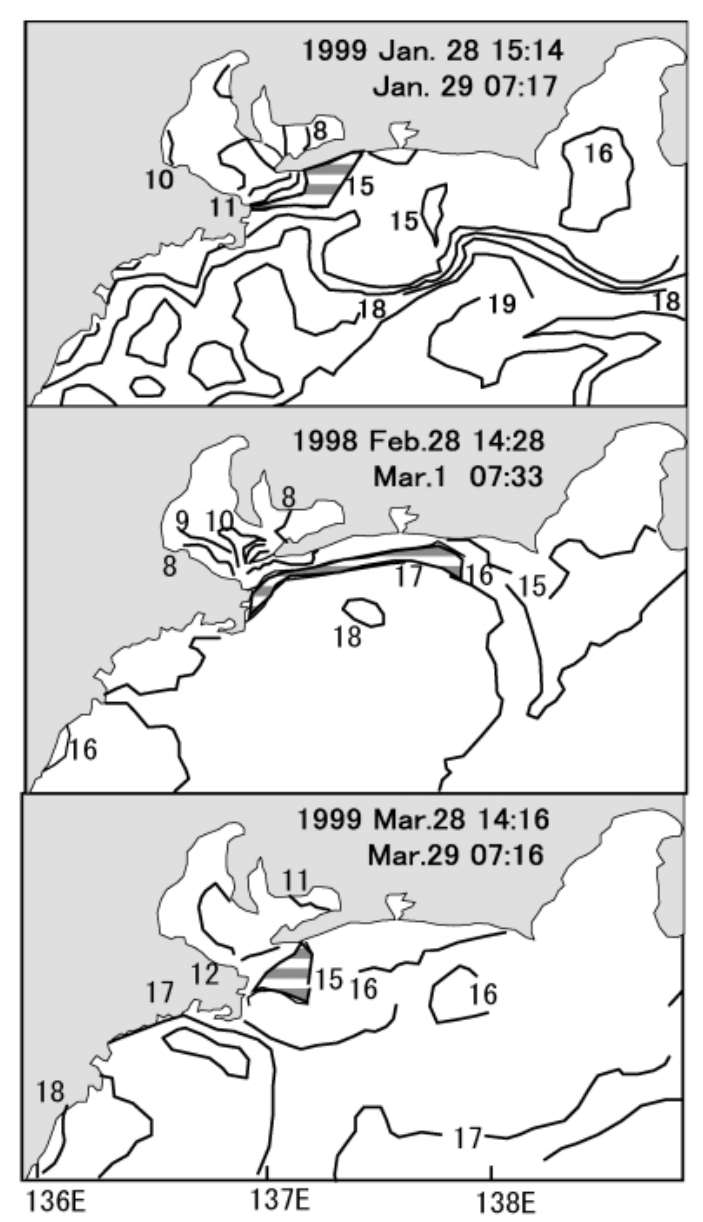

Fig. 9 Sea surface temperature images obtained by the satellite NOAA (January-March). Striped line zones show the estimated distribution areas of $\mathrm{C}-3$.

部産卵場からやや北東方向に移動した（Fig. 3)。C-2 は 10 月に熊野灘の南部海域（東経約 $136^{\circ}$ ) で再捕され た。C-2 のタイムシリーズログファイルに記録された日 々の推定位置は, 放流地点である東経 $137^{\circ}$ から放流後 西方へ変化する傾向を示し (Fig. 4), C-2 が熊野灘を南 下して再捕位置まで移動したことがうかがえた。また， C-3 は 1 年後に安乗沖産卵場で再捕されたが，C-3 の推 定位置を水温情報によって検証した結果, 放流後 6 月 にかけては伊勢湾への移動が示され，冬季は伊勢湾口部 から遠州灘海域内に分布したと考えられた。このよう に，アーカイバルタグ標識魚の移動は 2 カ年のディス クタグ標識放流試験結果とも良く一致し，標識魚は周年 にわたり放流地点から経度で東西に約 $2^{\circ}$ お抢よそ熊野 灘・遠州灘海域内で移動していたと判断された。トラフ グの遊泳速度に関して, 安井ら年は, 遠州灘でピン ガーを装着し放流したトラフグの平均移動速度は 17.5 $\mathrm{km} /$ 日と推定し, 過去の標識放流魚の短期再捕事例から 求めた $14.2 \mathrm{~km} /$ 日と類似した結果を得ている。濱田 ${ }^{16)}$
によると, 豊前海福岡県地先に放流された標識魚は放流 4 日後に最大 $7.25 \mathrm{~km} /$ 日の移動速度を記録した。ま た, 放流 22 日以降の再捕魚の移動速度は最大 $1.32 \mathrm{~km} /$ 日と推定された。遊泳速度は行動様式の相違や海域の潮

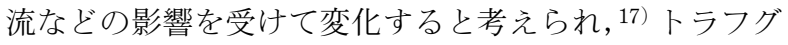
においても計測条件によって遊泳速度は異なるものと考 えられる。仮に, トラフグの遊泳速度が前述した安井 ら ${ }^{15)}$ の推定值 $17.5 \mathrm{~km} /$ 日で代用されるとすると, 東西 方向に $1^{\circ}$ (約 $\left.90 \mathrm{~km}\right)$ 移動するのに最短でも 5 日を要 する。Fig. 4 に示されたC-2 の 6 月 7 日は東経 $137.8^{\circ}$, 8 日は $133.4^{\circ}$ と位置推定されており, 少なくとも 1 日に $4^{\circ}$ 移動したことになるが, 1 日の移動距離としては明ら かに大きすぎると考えられる。このような異常と考えら れる位置推定值は C-3 の 11 月 3 日（東経 $136.3^{\circ}$ ) 4 日 （東経 $141.1^{\circ}$ ）など, 放流地点から経度で $2^{\circ}$ 以上離れた 推定值に多く見られた。今後は, アーカイバルタグの位 置推定值にトラフグの移動速度の概念を導入する事がで きれば, より精度の高い位置推定が可能になると考えら れる。

伊勢湾口部産卵場への回帰について 1996 年に放流 したディスクタグ標識放流群のうち 4 個体が, 放流翌 年の産卵期に 1 年前に漁獲された伊勢湾口部の安乗沖 産卵場で再捕された。さらに, 1998 年に放流したアー カイバルタグ装着トラフグ 1 個体も, 放流 1 年後に安 乗沖産卵場で再捕され, これら5個体は産卵のために 放流 1 年後に同一の産卵場に回帰したと考えられた。 また，1997年に放流したディスクタグ標識群のうち 1 個体は 1998 年 4 月 29 日に伊勢湾口部安乗沖産卵場に 近接し, 産卵場からやや北東方向に位置する遠州灘の西 部海域で小型底曳網により再捕された。前述のと抢り標 識トラフグは, 産卵後に産卵場の東方に位置する遠州灘 に移動する事例が多かったことから，この個体も伊勢湾 口部の安乗沖産卵場に産卵回帰後東方へ移動中に再捕さ れた可能性があると考えられる。なお，近年の調査で, 伊勢湾口部には安乗沖産卵場の北東方向に位置する伊良 湖沖にも産卵場が存在する18)ことが明らかになってお り, 前述の標識再捕個体は伊良湖沖産卵場への移動も考 えられる。いずれにしても, 調査期間中 3 力年の産卵 期に標識トラフグはすべて伊勢湾口部産卵場でのみ再捕 され，他海域での再捕報告は一例も無かった。伊藤ら ${ }^{4)}$ は, 遠州灘海域で放流した標識魚が産卵期およびその直 前の 3 5 月に産卵場がある伊勢湾口において再捕され ていることから, 遠州灘海域のトラフグ成魚は産卵期に は伊勢湾口部へ産卵回遊すると考えている。C-3 のデイ ログファイルのデータから冬季の水平移動を経時的にみ ると，C-3 は 1 月下旬から 2 月にかけては伊勢湾口部 加遠州灘海域内に，3 月中旬以降は伊勢湾口部周辺海 域に分布したと考えられ, 少なくとも 3 月中旬頃には 
産卵場のある伊勢湾口部周辺海域に移動したものと推察 された。これらのことから，トラフグ成魚は産卵期直前 の 3 月頃になると遠州灘から伊勢湾口部産卵場へ産卵 回遊を行うことが示唆された。

このように, 本標識放流試験結果は, 遠州灘, 熊野灘 の沿岸域に生息するトラフグは主に同海域内で移動回遊 を行うという従来の知見 ${ }^{3,4)}$ を支持するとともに，伊勢 湾口部産卵場への回帰を示唆した。

産卵場における遊泳行動 アーカイバルタグに記録さ れた遊泳水深から, 産卵直前の C-3 の遊泳行動は次の ように変化した。放流後埋没行動を除けばほとんど表層 を遊泳していたが，翌年 4 月上旬には水深 $5 \sim 10 \mathrm{~m}$ 層 を主体に小刻みな鉛直移動を繰り返すようになり，さら に 11 日頃からは水深 $35 \sim 40 \mathrm{~m}$ 層への潜水が活発にな った。15 日には水深 $33 \mathrm{~m}$ 層から頻繁に水深 $10 \mathrm{~m}$ あた りまでの浮上を繰り返す遊泳行動が示された。この雄の 遊泳行動は, 1997 年 10 月に放流され翌年 4 月に安乗 沖産卵場で再捕されたアーカイバルタグ装着トラフグ雄 の遊泳行動 8 ) と極めて類似した。すなわち，この個体は 3 月末から再捕されるまでの約 10 日間 $35 \mathrm{~m}$ 層で浮上 を繰り返す遊泳行動を示した。安乗沖産卵場の水深は $35 \mathrm{~m}$ 前後であり, 水深 $33 \mathrm{~m}$ 層は産卵場の海底と考元 られる。トラフグの雄は産卵床に長くとどまり, 何回も 雌の産卵に当たることが知られている11)ことから，C-3 が産卵場で浮上を繰り返した遊泳行動は, 雄の産卵期特 有の行動と考えられた。C-3 はその鉛直分布と遊泳行動 から, 少なくとも 4 月 11 日には安乗沖産卵場へ回帰し たと考えられた。

他海域のトラフグとの関係について 次に, 遠州灘, 熊野灘海域以外での再捕例に基づき他海域との関係につ いて検討する。1988 年生まれの卓越年級が加入した 1989 年冬季に, 熊野灘南部海域の定置網に大量入網し た未成魚を用いた同海域に抢ける標識放流試験結果で は, 標識魚は南下傾向を示し, その中の 1 尾は室戸岬 沖で再捕された。2) 安井ら ${ }^{3)}$ が遠州灘海域に放流した標 識トラフグの遠距離移動例は, 東は千葉県九十九里, 西 は徳島県牟岐町沖であり, 西方への移動に関しては同様 な海域であった。小島ら ${ }^{19)}$ は徳島県での標識放流試験 結果から, 同県で漁獲されるトラフグは瀬戸内海備讃瀬 戸産卵場に発生起源を持つと推定した。しかし，1989 年 7 月頃大量に漁獲された $1+$ 歳魚の発生起源は明らか でなく，しかも翌年の 1 月まで大きな移動をしなかっ たと報じている。したがって，この1+歳魚は 1989 年 冬季に熊野灘を南下した個体群である可能性が強いと考 えられる。佐藤ら 20 によると, 関門海峡と布㺫瀬戸で 発生したトラフグが伊予灘, 豊後水道域で混合している ことが推察されている。抢そらく, 遠州灘, 熊野灘に生 息するトラフグは, 1989 年のような卓越年級群発生時
にはその分布域を拡大し, 紀伊水道等隣接海域で瀬戸内 海産トラフグと分布が重なったものと考えられる。さら に, 佐藤ら ${ }^{20)}$ は伊勢湾口部産トラフグと瀬戸内海産卜 ラフグとの間には遺伝子頻度等に有意差が認められ，そ れぞれが独立した系群であることを示唆していることか ら, 前述の卓越年級群は紀伊水道等隣接海域から再び伊 勢湾口部の産卵場に回帰したと推察された。

\section{謝辞}

本研究をとりまとめるにあたり, 東京海洋大学東海正 博士には適切なるご指導を頂いた。また, 独立行政法人 水産総合研究センター中央水産研究所佐藤良三博士には 貴重なご意見を頂いた。本研究の実施にあたっては, 三 重県科学技術振興センター水産研究部藤田主任研究員打 よび津本主任研究員には調査の協力を, 久野研究員には 人工衛星画像の提供を頂いた。ここに，心より感謝申し 上げる。

\section{文献}

1）船越茂雄. 平成元年の太平洋におけるトラフグの特異豊 漁現象について一遠州灘から伊勢湾口を中心として一. 水産海洋研究 1990; 54: 322-323.

2) 中島博司. 熊野灘, 遠州灘海域のトラフグ資源につい て. 水産海洋研究 $1991 ; 55: 246-251$.

3）安井 港, 濱田貴史. 遠州灘・駿河湾海域におけるトラ フグの標識放流結果からみた移動. 静岡水試研報 1996; 31: 1-6.

4）伊藤正木, 安井 港, 津久井文夫, 多部田 修. 標識放 流結果から推定した遠州灘におけるトラフグ成魚の移動 ・回遊. 日水誌 $1999 ; \mathbf{6 5}$ : 175-181.

5）神谷直明, 辻ヶ堂諦, 岡田一宏 : 伊勢湾口部安乗沖にお けるトラフグ産卵場. 栽培技研 1992; 20: 109-115.

6）伊藤正木 : 移動と回遊からみた系群.「トラフグの漁業と 資源管理」（多部田 修編）恒星社厚生閣, 東京. 1997; $28-40$.

7）佐藤良三, 鈴木伸洋, 柴田玲奈, 山本正直. トラフグ Takifugu rubripes 親魚の瀬戸内海・布刈瀬戸の産卵場へ の回帰性. 日水誌 $1999 ; \mathbf{6 5}$ : 689-694.

8) Nakajima H, Nitta A. Notes about the ecology of ocellate puffer, Takifugu rubripes, using archival tags. In: JR Sibert, Nielsen JL (eds) Electronic Tagging and Tracking in Marine Fisheries. Kluwer Academic Publishers, London. 2001; 279-287.

9) Tokai T, Sato R, Ito H, Kitahara T. Year-class strength of the ocellate puffer around a spawning area in the inland sea of Japan. Nippon Suisan Gakkaishi 1993; 59: 245-252.

10）尾串好隆. 黄海・東シナ海産トラフグの年齢と成長. 山 口県外海水産試験場研究報告 1987; 22: 30-36.

11）藤田矢郎. 日本近海のフグ類. 「水産研究叢書 $39 」$ 日本 水産資源保護協会, 東京. 1988; 50-60.

12) Metcalfe JD. Summary report of a workshop on daylight measurements for geolocation in animal telemetry. In: JR Sibert, Nielsen JL (eds) Electronic Tagging and Tracking in Marine Fisheries. Kluwer Academic Publishers, London. 2001; 331-342.

13) Welch DW, Eveson JP. An assessment of light-based geoposition estimates from archival tags. Can. J. Fish. 
Aquat. Sci. 1999; 56: 1317-1327.

14）岩田静夫. 定地水温を使った海況図解析．神水試研報 1994; 15: 55-59.

15）安井 港, 森 訓由, 福世傳左卫門. 沿岸域におけるト ラフグの移動 バイオテレメトリーによる測定の一例. 静岡水試研報 1997; 32: 31-33.

16）濱田弘之. 標識放流からみたトラフグ 1 歳魚の分布, 移 動. 福岡水技研報 1994; 2: 21-31.

17）添田秀男，余座和征，嶋村哲哉. サケ．「テレメトリーに よる水生生物の行動解析」（添田秀男編）恒星社厚生閣,
東京. 1992; 41-54.

18）白木谷卓哉, 田中健二, 岩田靖宏, 家田喜一, 石川雅 章. 伊勢湾口部におけるトラフグの産卵場及び産卵時 期. 愛知水試研報 2002; 9: 27-31.

19）小島 博, 城 泰彦, 上田幸男, 石田陽司. 徳島県に来 遊したトラフグおよびトラフグ人工種苗の標識放流. 栽 培技研 1990; 19: 41-49.

20）佐藤良三，小嶋喜久雄. トラフグの分布・回遊特性. 漁 業資源研究会議報 1995; 29: 101-113. 